\title{
IMPLIED AUDIENCES IN THE AREOPAGUS NARRATIVE
}

\author{
Patrick Gray
}

\begin{abstract}
Summary
Much of the commentary tradition on Acts 17:16-34 too quickly glosses over the inclusion of Paul's sermon in a larger narrative context, focusing instead on the religionsgeschichtliche background of the speech or its compatibility with Pauline thought as expressed in the epistles. This essay brackets many of the questions that have occupied the history of the interpretation so as to highlight questions of literary and theological function. Close attention to Luke's compositional technique reveals the ways in which the Areopoagus narrative is not aimed at a monolithic Gentile audience but rather engages multiple implied readers while recapitulating many of the leading Lukan motifs in the mission to the Jews. The portrayal of Paul and of the responses of the Athenians to his message is suggestive of how Luke answers for his readers the question posed by Tertullian a century later, 'What hath Athens to do with Jerusalem?'
\end{abstract}

\section{Introduction}

Paul's address before the Areopagus in Acts 17 counts as one of the most celebrated passages in the NT. It has been read variously as an expression of natural theology rooted in Stoic thought, ${ }^{1}$ as a Christian sermon aimed at Gentiles yet steeped in biblical language and thought

1 Martin Dibelius, 'Paul on the Areopagus', in Studies in the Acts of the Apostles (ed. H. Greeven; tr. M. Ling; New York: Scribner's, 1956): 26-77; and Walter Eltester, 'Schöpfungsoffenbarung und natürliche Theologie im frühen Christentum', NTS 3 (1957): 93-114. 
patterns, ${ }^{2}$ as a gauge of Luke's reliability as a historian, ${ }^{3}$ as a source for reconstructing Paul's missionary modus operandi, ${ }^{4}$ and as evidence for or against its Pauline authorship vis-à-vis the epistles ${ }^{5}$ - and this sampling is by no means exhaustive. ${ }^{6}$ From the earliest Christian references to this text it is apparent that it functioned as an archetypal representation of the perennial conflict between between faith and philosophy (Tertullian, Praesc. 7:9; Jerome, Eph. 22:29). Irenaeus quotes the passage at length ( $A d v$. haer. 3:12:9) and twice points out that no Jews were present to hear Paul speak. Commentators concur on this point; Luke, through Paul, 'is addressing himself to the popular philosophies, the Volksglaube of the average Greek' ${ }^{7}$ Closer scrutiny of Luke's narrative technique, however, reveals a more complicated picture. Rather than aiming the speech at a monolithic Gentile audience, the author engages multiple implied readers while recapitulating many of the leading Lukan motifs in the mission to the Jews. To appreciate this layered quality, it is necessary to bracket some of the questions which have occupied the history of the interpretation of Acts 17:16-34 and to highlight questions of literary and theological function raised by the inclusion of Paul's speech in its larger narrative framework.

2 The most thorough presentation of this view is that of Bertil Gärtner; The Areopagus Speech and Natural Revelation (trans. C. H. King; ASNU 21; Uppsala: Almquist \& Wiksells, 1955).

3 Differing assessments are given by Ernst Haenchen, The Acts of the Apostles (trans. R. McL. Wilson; Philadelphia: Westminster, 1971): 517-31; and N. B. Stonehouse, Paul Before the Areopagus and Other New Testament Studies (Grand Rapids: Eerdmans, 1957): 1-40.

4 Stephen G. Wilson, The Gentiles and the Gentile Mission in Luke-Acts (SNTSMS 23; Cambridge: CUP, 1973): 196-218.

5 Along with Dibelius, who argues against the Pauline character of the speech, see Philipp Vielhauer, 'On the "Paulinism" of Acts', in Studies in Luke-Acts (ed. L. E. Keck and J. L. Martyn; Nashville: Abingdon, 1966): 34-37; and in the same volume, Hans Conzelmann, 'The Address of Paul on the Areopagus', 217-30. In addition to Gärtner, who regards it as essentially Pauline, see Wilhelm Schmid, 'Die Rede des Apostels Paulus vor den Philosophen und Areopagiten in Athen', Philologus 95 (1942): 79-120; and Wolfgang Nauck, 'Die Tradition und Komposition der Areopagrede', ZTK 53 (1956): 11-52.

6 The secondary literature is legion. For a survey of older views, see H. Hommel, 'Neue Forschungen zur Areopagrede Acta 17', ZNW 46 (1955): 145-78. Joseph A. Fitzmyer brings the bibliography on this passage up to date in his commentary (The Acts of the Apostles [AB 31; New York: Doubleday, 1998]: 613-17).

7 Wilson, The Gentiles and the Gentile Mission in Luke-Acts: 196. See also Haenchen, The Acts of the Apostles: 528: 'Paul speaks in a sense to the whole of Athens, and Athens again represents the whole of Greek culture and religiosity.' 


\section{Narrative Context}

The Areopagus scene falls in the second half of the book, after the Jerusalem council sets the official terms on which the Gentile mission may proceed in Acts 15:1-29. This is a watershed event in Luke's story-world. The previous chapters build to a point of conflict at the geographic center of the narrative - Jerusalem - and the dramatic tension is relieved considerably with the rejoicing of the Gentiles in Antioch upon the reading of the council's letter (15:30-31). Considering the space devoted to this decision, one would expect the Gentile mission to proceed with all haste. But one must wait for two chapters before Paul reaches Athens and delivers the first post-council proclamation to a purely Gentile audience. This delay discourages the reader from viewing subsequent mission work as focused exclusively on the uncircumcised. Paul's circumcision of Timothy in Acts 16:1-3 reinforces this perspective. Nor is the mission depicted as terribly successful, as Paul and Silas are imprisoned in Philippi and run out of Thessalonica by a mixed band of thugs for hire (Acts 17:5). Just because Jerusalem has decided to accept the Gentiles, it does not necessarily mean that the Gentiles will accept the good news from Jerusalem.

This ordering of episodes, then, hardly induces the reader to expect a triumphal entry into Athens. Paul's entry into Rome in Acts 28:1415, rather than Athens, is sometimes paralleled with Jesus' entry into Jerusalem in Luke 19, but the utter lack of ceremony associated with his arrival at the intellectual capital of the ancient world is telling. The staging of Jesus' entry into Jerusalem is like that of a special royal function, with Jesus fully in charge ${ }^{8}$ Paul, in contrast, is conspicuously passive. He is taken to Athens after the Jews of Thessalonica again incite the rabble (Acts 17:15). Paul finds himself in Athens almost by accident. That Athens is not an intended destination is evident from Acts 15:36, where Paul and Barnabas decide to go back and visit those in each city where they had already proclaimed the word. A victim of circumstance, he leaves Berea in order to escape the mob from Thessalonica. Instead of being greeted by a crowd, Paul is apparently left alone after sending a message to Silas and Timothy. The first address Luke records of the 'official' Gentile mission could not have been introduced less auspiciously.

8 Cf. David L. Tiede, Luke (ACNT; Minneapolis: Augsburg, 1988): 329. 


\section{The Speech and its Immediate Setting}

Paul is simply waiting in Athens until the sight of idols at every turn drives him to distraction. Luke assumes on the part of his readers a basic familiarity with Athens' reputation as a cultural crossroads and as the seat of philosophy in the first-century Mediterranean world. Despite Paul's perception of pervasive idolatry, the setting differs markedly from the less cosmopolitan Lystra, the previous Gentile setting in which Paul preaches (14:8-18). Such diverse cultural settings as those in which Luke's characters find themselves carry certain extratextual connotations for the reader and raise expectations which contribute to characterization and plot development. ${ }^{9}$ How will Paul react when vexed by idolatry? What will he say? And how will the Athenians respond to his message?

At this juncture a shift in setting delays the dramatic resolution of the conflict. Paul, provoked by the idolatry of the Athenians in verse 16 , 'was therefore debating in the synagogue with the Jews and with the devout persons'. This first clause of verse 17 at first glance appears to be an interpolation that disrupts the flow of the scene. Paul's appearance in the synagogue is abrupt and unexplained. Conzelmann, however, holds that it has a firm position in the Lukan pattern of starting missionary work in the synagogue. ${ }^{10}$ Numerous times in Acts Luke makes use of the same formula: Paul arrives, preaches in the synagogue, and receives a positive hearing until the Jews incite the rabble and Paul turns to the Gentiles. Luke shapes the scenes at Pisidian Antioch (Acts 13:13-41), Iconium (14:1-7), Thessalonica (17:1-9), Berea (17:10-14), and Ephesus (19:8-20) through this pattern. There is no clash with the Jews in Athens to precipitate the turn to the Gentiles as there is in other cities. The conclusion Conzelmann draws is that since there is no such developed conflict in Athens, Luke's sources are scanty and so he uses the pattern mechanically. Paul returns to the synagogue after the first two of the three statements announcing the end of the mission to the Jews (Acts 13:46; 18:6; 28:28), thus the repeated use of the literary pattern produces an apparent inconsistency within the narrative. ${ }^{11}$

9 John A. Darr, On Character Building: The Reader and the Rhetoric of Characterization in Luke-Acts (Louisville: Westminster/John Knox, 1992): 40.

10 Conzelmann, 'The Address of Paul on the Areopagus', 219.

11 Cf. Joseph B. Tyson, The Death of Jesus in Luke-Acts (Columbia: University of South Carolina Press, 1986): 42-43, who adds that 'Paul rejects any further mission to 
Conzelmann's conclusion, however, is far from certain. Whether Paul actually went to the synagogue in Athens is ultimately unanswerable from a historical perspective, but Conzelmann begs the question when it comes to Paul's reasons for visiting the Jews. As the evidence could be argued in the opposite direction with equal force, it is clear that literary 'patterns' devoid of plot analysis can become arbitrary. If Luke has Paul go to the synagogue only to fulfill the requirements of a pattern, the causal sequence of events is compromised and the plot's structure is weakened. This would undermine Luke's objective - stated in the prologue of the gospel - of providing $\alpha \sigma \phi \alpha \dot{\lambda} \varepsilon \alpha_{\alpha} \alpha$, because the addition of a digressive episode would compromise the orderly sequence of events (recounted $\kappa \alpha \theta \varepsilon \xi \hat{\eta} \varsigma$ ) which he has been following intently ( $\pi \alpha \rho \eta \kappa о \lambda о v \theta \eta \kappa o ́ \tau \imath)$. If it is Luke's intention to provide and 'orderly account', then one has cause to pay special attention to his chronological markers and narrative transitions, not only between one episode and another but also within the framework of a single episode.

Reducing verse 17 to a literary convention, moreover, prevents Luke from using the Athens scene to develop the link between the Jewish and Gentile missions in his construction of early Christian history. Paul's return to the synagogue is in part a consequence of his exposure to Athenian idolatry. The narrative transition $\mu \dot{\varepsilon} v$ oûv strengthens the causal chain connecting the events in verses 16-17. This particle does not always require translation (cf. Acts $1: 18 ; 2: 41 ; 5: 41$ ). ${ }^{12}$ Many commentators do not translate it, but this decision should not be based on a predetermined construal of Luke's rhetorical goals, historical reliability, or use of source material. In this instance, translating the verse as literally as possible is more responsible because it does not prematurely close off any particular avenue of exegetical inquiry.

That the Athens scene functions as one in a 'series of symbolic encounters between the word of the gospel and the many aspects of the world it was destined to transform' is undeniable. ${ }^{13}$ That this encounter can be best understood without the background of the Jewish mission,

the Jews, but he must resume it because the literary pattern demands it.' Although Tyson does not refer directly to the scene at Athens, his reasoning is often applied to Paul's appearance at the synagogue in Acts 17:17.

12 BDF § 451.

13 Luke T. Johnson, The Acts of the Apostles (SP 5; Collegeville, Minn.: Liturgical, 1992): 319 . 
however, is the other extreme to be avoided. Paul's mission to the Gentiles in turn sheds light on the mission to the Jews. The two are mutually interpretive. The Jews are not simply a foil to the virtuous pagans Paul meets in his travels around the Mediterranean. Paul's negative impression of Athens upon his first exposure to the city sends him back, if only briefly, to the synagogue.

\section{Lukan Characters and Lukan Theology}

Luke's characterization of the Athenians in Acts 17:18-21 militates against the view that God, despite the seemingly final turn to the Gentiles in 28:28, intends to 'replace' the Jews with non-Jews. When Luke first allows the Athenians to speak in verse 18, they mock Paul as a 'babbler' ( $\sigma \pi \varepsilon \rho \mu о \lambda o ́ \gamma o \varsigma)$. Their reaction to him is scarcely better than that of the Jews in other cities, only less violent. The narrative aside in verse 21, where Luke states that 'all the Athenians and those residing there used to spend their time in nothing besides listening to or sharing some new thing', further diminishes Paul's audience in the eye's of Luke's audience. In Luke's estimation, the Athenians are the real babblers, who flit from place to place sampling morsels of learning from whatever speakers happen to appear and thinking themselves the wiser for it. Their desire to know about Paul's 'new teaching' (v. 19) is not to be seen as healthy curiosity. ${ }^{14}$ Novelty possesses a negative valence throughout the biblical tradition and elsewhere in the GrecoRoman world. Early Christians knew that they were susceptible on this score - their message was emphatically a new one, no matter how much Stephen and others might stress its continuity with Jewish tradition. Later in his speech (v. 28) Paul quotes from a verse of Aratus (Phaenomena 5) and perhaps also from Epimenides, and in so doing

\footnotetext{
14 Greek and Roman writers rue the fact that idle curiosity into worthless matters is all too common among the people (Cicero, Off. 1:18-19; Seneca, Eph. 88:36-38). Plutarch's essay De curiositate is perhaps the most famous treatment of the topic. For Plutarch, curiosity is an unhealthy state of mind too often coupled with envy and malice (Curios. 513D). Such busybodies accordingly neglect their own faults and focus instead on those of others $(516 \mathrm{D}, 516 \mathrm{~A}, \mathrm{D})$. Old stories hold little appeal for the curious, who have an appetite only for novelties (517F, 519A-B). They cannot endure the quiet of the countryside and are forever visiting the agora - anything to get the latest gossip and to divert their attention from their own troubles (519A-B, 521D).
} 
takes a subtle swipe at his audience. ${ }^{15}$ By juxtaposing Paul's appeal to venerable philosophical tradition alongside the Athenians' fascination with novelties, Luke is able to flesh out his characters - Paul as well as his listeners - and to discourage his readers from regarding the Jews as unique in their inability, or unwillingness, to recognize the full implications of the tradition to which they are the heirs. ${ }^{16}$

In addition to their insatiable curiosity, the Athenians' imperceptiveness earns low marks from the narrator. Paul 'seems to be a proclaimer of foreign deities' because he is preaching about 'Jesus and the resurrection' (v. 18). Many interpreters see in this notice the suggestion that the Athenians have mistaken 'resurrection'

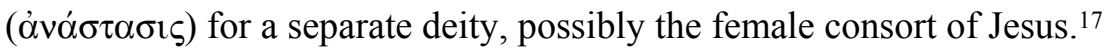
If this is the nuance Luke intends to communicate, their error is similar to the one made by the Gentiles at Lystra in Acts 14, where Paul and Barnabas are mistaken for Hermes and Zeus after healing a lame man. The positive, albeit improper, response of Lystra stands in contrast to the skepticism of Paul's audience in Athens. Secondary characters such as the Athenians are assessed by the narrator according to their ability to discern and embrace God's salvation as it is revealed in Jesus or proclaimed by the other protagonists in the narrative. ${ }^{18}$ The Athenians fail on this score as they lose interest in verse 32 when Paul mentions Jesus' rising from the dead. Their restlessness is perplexing given their initial interest in 'Jesus and the resurrection', which is virtually the only 'new teaching' in the entire speech. Luke constructs the scene so that the Athenians emerge as willfully ignorant. ${ }^{19}$

The function of this negative characterization, however, becomes more complicated when one recalls that Luke does not have Paul

15 On the sources of the quotations in v. 28, see Kirsopp Lake, 'Your Own Poets', in The Beginnings of Christianity: Part I, The Acts of the Apostles (ed. F. J. FoakesJackson and K. Lake; 5 vols.; London: Macmillan, 1920-33): 5:246-51; R. C. Horn, 'Classical Quotations and Allusions of St. Paul', LCQ 11 (1938): 281-88; and M. J. Edwards, 'Quoting Aratus: Acts 17,28', ZNW 83 (1992): 266-69.

16 Cf. Abraham J. Malherbe, ' Not in a Corner': Early Christian Apologetic in Acts 26:26', in Paul and the Popular Philosophers (Minneapolis: Fortress, 1989): 152.

17 Fitzmyer, Acts of the Apostles: 605. This construal goes back at least to John Chrysostom, Hom. Acts 38:1 (PG 60:267). On the conventions pertaining to the introduction of new deities, see Bruce W. Winter, 'On Introducing Gods to Athens: An Alternative Reading of Acts 17:18-20', TynB 47 (1996): 71-90.

18 Darr, On Character Building: 91-92.

19 On Luke's ambiguous references to their ignorance in vv. 23 and 30, see Mark D. Given, 'Not Either/Or but Both/And in Paul's Areopagus Speech', BibInt 3 (1995): $365-66$. 
address a uniform audience. In verse 17b Paul debates with whomever he chances to meet in the agora. Epicureans and Stoics are among those he encounters in verse 18a. 'The foreigners dwelling there' (v. 21) constitute yet another group distinct from the philosophers and the ordinary city-dwellers. At the conclusion of Paul's speech, some listeners scoff while others voice their intention to hear more later (v. 32). Dionysius the Areopagite and Damaris head a final group of Athenians who listen and believe.

This diversity accentuates the ambiguity of Paul's exordium. When Paul begins by observing that the Athenians are 'very religious in all respects' (NASV), it is customary in the commentary tradition to point out that he may be reproaching them for being 'too superstitious' (KJV). ${ }^{20}$ Although the negative connotation comes to predominate by

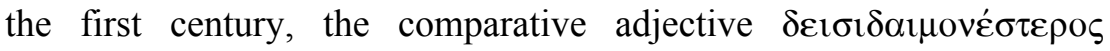
technically allows for either a negative or a positive sense. ${ }^{21}$ The Athenians may have been flattered by the epithet. Coming from Paul, though, it may indicate disapproval without prematurely antagonizing his audience. Members of a diverse audience might be disposed to respond in different ways on the basis of these opening remarks.

A number of interpreters have argued that the differing responses at the conclusion of Paul's speech correlate with the division between Stoics and Epicureans on such issues as divine providence or life after death. ${ }^{22}$ The connection between the ambiguous exordium and the presence of the philosophers has gone largely unnoticed..$^{23}$ Of all the

20 E.g. Haenchen Acts of the Apostles: 520; Johnson, Acts of the Apostles: 314; cf. also H. Armin Moellering, 'Deisidaimonia: A Footnote to Acts 17:22', Concordia Theological Quarterly 34 (1963): 471. The NEB strikes a fine balance: 'in everything that concerns religion you are uncommonly scrupulous.'

21 For the neutral or favorable sense, see Xenophon, Cyr. 3:3:58; Aristotle, Pol. 1315A; Aelian, Var. hist. 5:17; Heliodorus, Aeth. 10:9. The more common pejorative usage is seen in Theophrastus, Char. 16; Polybius 12:24:5; Philo, Gig. 16; Mut. 138; Plutarch, Quaest. rom. 287F; Amat. 756C; Superst. 164E-F et passim.

22 Jerome H. Neyrey focuses on the former ('Acts 17, Epicureans, and Theodicy: A Study in Stereotypes', in Greeks, Romans, and Christians: Essays in Honor of Abraham J. Malherbe [ed. D. Balch, E. Ferguson, and W. Meeks; Minneapolis: Fortress, 1990]: 127-29). N. Clayton Croy focuses on the latter ('Hellenistic Philosophies and the Preaching of the Resurrection [Acts 17:18, 32]', NovT 39 [1997]: 21-39).

23 Only C. K. Barrett ('Paul's Speech on the Areopagus', in New Testament Christianity for Africa and the World [ed. M. Glasswell ad E. Fasholé-Luke; London: SPCK, 1974]: 74-75) has remarked on it. Mark D. Given comments more generally on the ironic function of Paul's ambiguity, noting that the Stoics, unlike the Epicureans, were especially proud of their skill in detecting ambiguities in philosophical arguments 
groups susceptible to the charge that they are superstitious, these schools are the least likely. Whatever internecine debates separated the Stoics and Epicureans, they were united in their antipathy toward anything smacking of superstition. Because $\delta \varepsilon 1 \sigma 1 \delta \alpha \iota \mu$ vi $\alpha$ is rooted linguistically as well as psychologically - in the emotion of fear, both schools regard it as a pathological state inimical to human flourishing. Stoics like Chrysippus include it in the standard taxonomies of emotional response (SVF 3:394, 408, 409, 411). As one of the passions, it is to be extirpated. Epicurean attacks on superstition could be so withering that Plutarch - himself a harsh critic of $\delta \varepsilon 1 \sigma 1 \delta \alpha 1 \mu$ oví $\alpha$ - on occasion feels the need to defend popular religious observances on the grounds that religion run to extremes is better than no religion at all (Suav. viv. 1101C; Adv. Col. 1124D-1125A). Luke has Paul salute his audience in terms that are anathema to the philosophers in attendance. This conforms to Luke's habit, seen in the gospel and Acts, of making distinctions between various groups and their response to his protagonists. $^{24}$ Up to this point Luke's characters have been predominantly Jewish. In the Athens episode Luke pursues a similar literary-rhetorical strategy with a Gentile cast. His mention of the Stoics and Epicureans in the narrative frame is not simply a matter of name-dropping to add local color to the scene.

To classify the speech as a representative encounter with the classical world as an undifferentiated whole is to overlook the fact that Stoics and Epicureans are atypical of ancient audiences insofar as they would have agreed with Paul that the idol-worshipping Athenians were superstitious. In this respect Luke weds the philosophical criticism of popular religiosity to longstanding Jewish attacks on pagan idolatry. Paul describes the beliefs and practices he has witnessed in Athens as

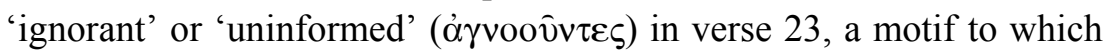
he returns in verse 30 . Ignorance - chiefly but not exclusively of the gods' true nature and of their dealings with humans - is a core component of Hellenistic critiques of superstition. ${ }^{25}$ It is likewise a

('The Unknown Paul: Philosophers and Sophists in Acts 17', in Society of Biblical Literature 1996 Seminar Papers, 35, ed. E. H. Lovering [Atlanta: Scholars, 1996]: 343-51).

24 See, for example, the way Luke has Paul subtly but consciously drive a wedge between the Pharisees and Sadducees as he begins his defense speech before the council in Acts 23.

25 Cicero, Nat. d. 1:42.117; Div. 1:4.7; 2:6.19; Dom. 40:105; Diogenes Laertius 2:9192; Plutarch, Superst. 164E-F, 165C; Gen. Socr. 579F; Per. 6:1; Aem. Paul. 1:5. 
recurring theme in Luke-Acts. The disciples 'do not understand' when Jesus foretells his passion in Luke 9:44-45. Jesus asks God to forgive those responsible for his death on the cross, 'for they know not what they do' (Luke 23:34). Peter preaches that it was in ignorance that the Jews delivered Jesus to his executors (Acts 3:17). Just as Paul's criticism of Athenian worship (Acts 17:23-25, 29) finds a parallel in the Lukan perspective on Jewish attitudes toward the temple (e.g. Acts 7:48-50), the motif of ignorance and its association with a Gentile audience is an echo of the Jewish ignorance one sees earlier in the narrative. ${ }^{26}$

Paul therefore invites the philosophers to align themselves with a superior form of Judaism over against the less sophisticated adherents of both the pagan and the biblical religions. Surveyors of the religious landscape in the first-century Mediterranean regularly attached the label of superstition to Jews and, by extension, to Christians (Plutarch, Superst. 169C; Tacitus, Ann. 2:85; 15:44; Juvenal, Sat. 14:99). A pagan like Seneca or Plutarch was capable of recognizing variety within these movements, perhaps even regarding some versions as more enlightened than the religious sensibilities of his fellow pagans. In a pluralistic society there will often be sub-groups in separate religious traditions that share many traits in common that neither subgroup shares with other sub-groups within its own tradition. For example, liberal or conservative Baptists or Catholics may have as much or even more in common with each other than either has in common with their co-religionists at the opposite end of the spectrum.

26 Paul's comment on Athenian religiosity is often interpreted as a fairly charitable assessment of Gentile idolatry and ignorance. According to Günther Bornkamm, the Gentiles' past is re-evaluated by Luke as a preparatory prelude ('The Missionary Stance of Paul in I Corinthians 9 and Acts', in Keck and Martyn, Studies in Luke-Acts: 202). The gospel in this view is an apologia not only proclaiming the fulfillment of OT prophecy concerning the Messiah, but also affirming Greek traditions concerning the natural divine origin of all peoples and their proximity to God. But this very proximity undermines the excuse that Gentiles have not turned to the God of Israel because they

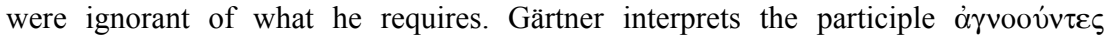
negatively, as a lapse from God and not simply a case of being epistemologically in the wrong place at the wrong time (The Areopagus Speech and Natural Revelation: 237). This reading seems to fit better with Paul's mental state in v. $16-\pi \alpha \rho o \xi v$ veıv is also used in the LXX to express God's provocation at idolatry (Deut. 32:16, 21; Hos. 8:5) and with the call to repentance in v. 30. It is over the 'times of ignorance' that God's judgment falls, necessitating repentance. Paul's call to repentance is more compressed but no less urgent than John the Baptist's in Luke 3. John anticipates the first coming of Jesus while Paul anticipates the second. 
The strategy of laying out the common ground between the biblical views of God and the world and those of the Epicureans and Stoics succeeds in securing a temporary hearing at the Areopagus, but it ultimately produces only negligible results. Among Luke's audience, however, matters are different. Luke writes for those already catechized in the Christian faith (Luke 1:1-4). He chooses to include this Pauline appeal to outsiders in his narrative composed for the sake of insiders. Unlike Paul's audience in Athens, Luke's audience consists, perhaps exclusively, of individuals who have followed the example of Dionysius and Damaris rather than that of the philosophers. This is the case whether they are mostly Jews or mostly Gentiles. If his audience is largely Gentile - as a majority of scholars have argued - they are in a special sense hearing their own story retold through the medium of the Areopagus narrative. Luke may not be writing an evangelistic tract intended to win over new converts, but he is almost certainly writing to those who have converted sometime in the recent past and thus have some recollection of the process, be it sudden or gradual, whereby they came into the Christian fold. ${ }^{27}$

Since it is possible to be fully aware of what it means to be converted only after the fact, the retrospective nature of conversion accounts is unavoidable. ${ }^{28}$ This observation applies equally to Luke and Paul, as well as to their respective audiences. While the Areopagus narrative is not a first-person account, Luke's re-presentation of a paradigmatic instance in which Gentiles 'turn to God from idols to serve the living and true God' (1 Thess. 1:9) provides the occasion for his readers to consider the significance of their own conversions. A form of supersessionism represents one possible way for Luke's audience to construe the historical dynamics by which Christianity became a predominantly Gentile movement. ${ }^{29}$ That an implied Gentile reader could conclude from this demographic reality that a class of

27 Cf. Beverly Roberts Gaventa, From Darkness to Light: Aspects of Conversion in the New Testament (OBT 20; Philadelphia: Fortress, 1986): 150.

28 Paula Fredriksen, 'Paul and Augustine: Conversion Narratives, Orthodox Traditions, and the Retrospective Self', JTS n.s. 37 (1986): 33. See also Kierkegaard's aphorism: 'Life can only be understood backwards, but it can only be lived forwards' (cf. Papers and Journals: A Selection [trans. A. Hannay; London: Penguin, 1996]: 161).

29 Rodney Stark, however, builds a provocative case from a sociological and statistical perspective that Christianity's rapid growth is attributable to the relative success of the Jewish mission (The Rise of Christianity [Princeton: Princeton University Press, 1996]: 49-71). 
non-Jews had in some sense replaced the Jews as God's chosen people is seen clearly in Paul's letter to Rome (esp. 11:1-32). Some interpreters implicate Luke in this construal of salvation history on account of the way he tells the story of the early church. Indeed, the bittersweet ending of Acts - the Gentiles 'will listen' but the ears of the Jews are 'heavy of hearing' - seems to lend itself to such a reading.

Gentile converts may therefore be excused for drawing supersessionist conclusions from the events Luke describes, but it would be a mistake to assume that this is the only way to discern the signs of the times. To avoid a supersessionist theology, one might raise the Jews to the level of God's favor purportedly enjoyed by Gentile Christians. But another strategy is to lower the Gentiles to the level purportedly attained by a disobedient Israel. The literary effect of Luke's portrayal of the Athenians moves in the latter direction. When Luke's readers see their own story re-enacted through the vehicle of the Areopagus narrative, they are reminded of a demographic reality running parallel to the results of the mission to the Jews. From the inside it may appear that the Gentile response to the gospel has been overwhelming in comparison to the Jewish response. An outside observer, however, sees only a trickle. To be sure, the majority of Jews in Luke's story-world do not convert to Christianity. But neither do the majority of Gentiles. The number of Gentiles who convert to Christianity, in Acts as well as in the real world of the first century, in all likelihood constitutes a proportion of all Gentiles that is no greater than the proportion of Jews who convert. Gentiles may overshadow Jews in the church in raw numbers, but they comprise a tiny minority over against the vast majority of their fellow Gentiles who failed to follow the example of Dionysius and Damaris. So while Gentile converts may enjoy a new status in God's eyes, their Gentile status is not a necessary or sufficient condition for divine favor. Luke's audience, like the handful of Athenians who join Paul, represents a 'remnant' of sorts similar to the remnant of Jews who come to regard Jesus as the messiah.

\section{Conclusion}

In Acts 17, Luke thus presents an episode in the ongoing story of the formation of God's people. Not all Jews, according to Luke, will fall in 
this new grouping. The Pharisees and others in Israel turn a deaf ear to the good news. Jesus' preaching functions as a 'sign of contradiction' (Luke 2:34) and as such creates a division among the people of Israel in the gospel. Paul's preaching about Jesus has the same effect in Acts, not only among his Jewish audiences but among his Gentile audiences as well. Some of the uncircumcised respond after the manner of Dionysius and Damaris or even the exuberant inhabitants of Lystra and Derbe, but many more are like the Epicureans and Stoics, if not as belligerent as Demetrius and the silversmiths in Ephesus. The Areopagus narrative recapitulates many theologoumena and motifs familiar from the OT or first appearing in Luke's portrayal of the Jewish mission, such as the image of God as creator and sustainer, the inability of man-made shrines to contain the deity, the idea that nature moves the heart to seek the God who has patiently endured the ignorance of humans, the universal necessity of repentance, and the march of history toward a day of judgment. ${ }^{30}$ This literary-theological echo effect corresponds to the way in which the corporate experience of the Gentiles follows a similar trajectory as that of the Jews with respect to conversion. When Lukan protagonists preach repentance, the reader recognizes that most members of most audiences will turn the other way.

Hollywood tends to distort religious history, but on at least one occasion it seems to have arrived at a basic but important insight that provides an excellent perspective on Paul's call for $\mu \varepsilon \tau \alpha \dot{v} v o t \alpha$ at the end of his speech and the reaction it provokes. The 1955 film The Silver Chalice, loosely based on portions of the apocryphal Acts of Peter, stars Paul Newman as Basil, a master silversmith. Joseph of Arimathea sends Luke, presumably the evangelist, to buy Basil out of slavery because the Christians in Jerusalem want him to craft a beautiful chalice to protect the cup used by Jesus at the Last Supper. When Basil expresses doubt that Christians place any value on fine art, Luke responds that Christians can change their minds: 'Why, every Christian you meet is a man who's changed his mind or else he wouldn't be a Christian'.

Whether Jew or Gentile, Luke's audience consists of men and women who have changed their minds or else they would not be

30 Paul Schubert, 'The Place of the Areopagus Speech in the Composition of Acts', in Transitions in Biblical Scholarship (ed. J. Coert Rylaarsdam; Chicago: University of Chicago Press, 1968): 253-59. 
Christians. ${ }^{31}$ Insofar as they are now Christians but once were not, Luke's readers have been on both sides of the threshold and thus share some experiences in common with all of the Athenian characters. The speech and its literary framework together contribute to characterization. Luke's characters in turn function as vehicles for theological reflection, and a reader's capacity for identifying with certain characters in a story makes possible the actualization of the text's meaning. The Areopagus narrative serves as a sobering reminder to Luke's readers that God's call to repentance, while directed at all irrespective of nation, will be ignored more often than not. In this light, the narrative mitigates the sense that the Jewish mission has been, by comparison with the Gentile mission, an utter or unique failure.

31 The biblical resonance of the Areopagus speech may imply the presence of scattered Jews in Paul's implied audience or may reflect a concern on Luke's part to present the good news in terms that speak to Jewish Christians in his own day. Notwithstanding the exceedingly sweeping yet quite common claim (e.g. Wilson, The Gentiles and the Gentile Mission in Luke-Acts: 246-47) that the Christian mission was limited exclusively to Gentiles when Luke is writing, it is very possible, even probable, that there remained in Luke's audience Jewish Christians who had converted years earlier when there was still an active, if not thriving, Jewish mission. Paul's sermon in this perspective has not only a Gentile audience in view but serves as an aid to Christians reflecting on the full significance of their conversion from Judaism as well. 